\title{
Prevalence of Ixodid Ticks on Local and Crossbred Cattle in Indo-Bhutan Border Districts of Assam, India
}

\author{
Dipanjali Mushahary, Kanta Bhattacharjee, Prabhat Chandra Sarmah, \\ Dilip Kr. Deka, Tirtha Nath Upadhyaya and Munmi Saikia* \\ Department of Parasitology, College of Veterinary Science, Khanapara, \\ Guwahati-781022, Assam, India
}

*Corresponding author

\begin{abstract}
A B S T R A C T
\section{Keywords}

Cattle, Assam, Indo-Bhutan border, Rhipicephalus (Boophilus) microplus, Haemaphysalis bispinosa

Article Info

Accepted:

17 April 2019 Available Online: 10 May 2019

The present study was conducted to know the diversity of tick species infesting domestic and crossbred cattle in 4 districts of Assam along the Indo-Bhutan border for one year. A total of 533 cattle were examined, $266(49.90 \%)$ were found infested either with Rhipicephalus (Boophilus) microplus $(23.45 \%)$ or Haemaphysalis bispinosa $(15.75 \%)$ or with both the ticks $(10.69 \%)$. Crossbred cattle were found having higher tick prevalence (53.50\%) compared to the indigenous $(49.34 \%)$ which was statistically non-significant. Infestation was highest in adult cattle > 3 years of age $(56.61 \%)$ and the lowest in calves < 1 year of age $(41.74 \%)$. Higher prevalence was recorded in female $(53.57 \%)$ than the males $(44.80 \%)$ and also higher in free ranged indigenous cattle $(49.34 \%)$ than that of crossbred stall fed cattle $(41.55 \%)$. According to the distribution of ticks on different body parts of cattle, infestation was observed highest in inguinal region including udder and external genitalia $(82.70 \%)$ followed by neck $(71.42 \%)$ and lowest seen in back region $(22.55 \%)$. Cattle and other animals are being regularly traded across the porous IndoBhutan border areas. Such activities can pose as the risk factors for transmission of various tick borne diseases. The level of infestation, seasonal epidemiology of ticks and associated management practices to adopt are discussed.
\end{abstract}

\section{Introduction}

India is predominantly an agricultural country with about $70 \%$ of its population dependent on income from agriculture. Livestock is an important source of animal protein for farm families and also used for draught purpose in agriculture and transport, and their dung is used to increase soil fertility under organic farming. Ticks are important ectoparasites which parasitize terrestrial vertebrates including livestock, humans, and companion animals mostly in tropical and sub-tropical areas and transmit pathogens to them. Jonsson et al., (1998) reported that a single engorged female tick is responsible for daily loss of 0.5 
to $2 \mathrm{ml}$ of blood and $1 \mathrm{~g}$ of body weight. Infestation of dairy cattle with Boophilus microplus and the brown ear tick, Rhipicephalus appendiculatus are known to cause a loss of $8.9 \mathrm{ml}$ and $9.0 \mathrm{ml}$ milk yield respectively. The direct effects on production include skin damage from tick bites, allergy, toxicosis, tick paralysis, reduced weight gain and milk production (Biswas, 2003; Sajid et al., 2007) and indirect effects are related to the transmission of tick borne pathogenic microorganisms including protozoa, rickettsiae and viruses. The Northeast India represents the transition between India, Myanmar, Bangladesh, China and Bhutan and is the geographical gateway for much of flora and fauna (Rai, 2008). Animal diseases often transcends international boundaries (Trans Border Animal Diseases-TADs) through unabated movement of animals, birds and other carrier agents and can become the cause of national emergencies so far the animal and human health are concerned (OIE, 2013). Bhutan, known as the "Thunder Dragon Country" is a tiny independent kingdom bordered in the east, west and south by the Indian states of Arunachal Pradesh, Sikkim, Assam and West Bengal, while in the north by China. The Duars plain areas in the South Bhutan, situated at an elevation of 700 feet above mean sea level and along the Indian border experience a hot, humid, subtropical climate with heavy rainfall. During winter, herds of cattle are brought down from the temperate areas of the country to the subtropical grazing areas along the Indian border. Among diseases of cattle, intestinal worm infection, ticks and leech infestation and tick borne diseases such as babesiosis, theileriosis and anaplasmosis are the major recognized problem in cattle of Bhutan (Phanchung et al., 2012; Tshering and Dorji, 2013). The border trade between the India and Bhutan takes place through several recognized passes or duars extending from Darjeeling foothills of West Bengal to the foothills of Arunachal Pradesh. Assam is the major state of which six districts such as Kokrajhr, Bongaigaon, Chirang, Baksa, Udalguri and Sonitpur covering approximately 1000 square miles area share boundary with Bhutan. Livestock for milk production and draught purpose are being regularly traded and can be considered to be the risk factors for transmission of various diseases and vectors. Therefore studies on these organisms are of great importance in monitoring and surveillance of transboundary animal diseases.

\section{Materials and Methods}

\section{Study area}

The present study was carried out for one year w.e.f. April 2016 to March 2017 in four districts of Assam namely, Kokrajhar, Chirang, Baksa and Udalguri representing the Indo-Bhutan border areas. These districts are located between $26.24^{\circ}-26.6897^{\circ} \mathrm{N}$ Latitude and $90.16^{\circ}-91.9099^{\circ} \mathrm{E}$ Longitude with environmental temperature ranging from $8^{\circ}$ to $15^{\circ} \mathrm{C}$ during winter and $35^{\circ}$ to $38^{\circ} \mathrm{C}$ during the summer.

Fig.1 Map of Assam showing four districts (Kokrajhar, Chirang, Baksa and Udalguri) bordering south of Bhutan

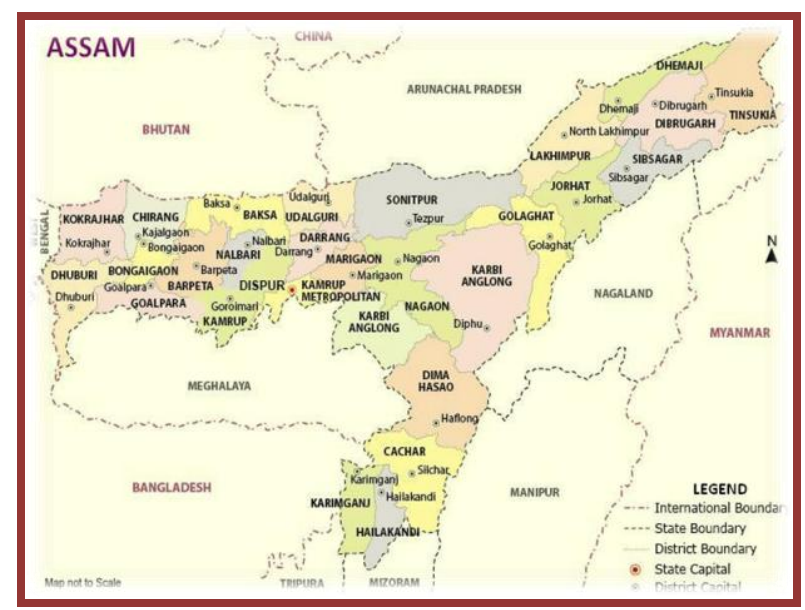




\section{Study design}

A total of 533 cattle (456 indigenous and 77 crossbred) were included to record the prevalence of ticks. The body of the animals were thoroughly examined by close inspection, palpation and parting the hairs against their natural direction for the detection of ticks if any. For this, different body parts such as ear and pinna, head, neck, brisket region, back, inguinal region including udder in females and scrotum in males, tail and tail switch were considered for screening. The different stages of ticks (larva, nymph and adult male and female) were collected from body regions of the infested cattle by hand picking. Utmost care was taken to keep the mouth parts and appendages of the ticks intact. Sometimes, ether was used during collection of tick, which made the ticks paralysed in order to facilitate their collection without any damage.

Collection of animal related data such as age, sex, breed and husbandry practices were made by interviewing the owners/farmers. According to age, animals were categorized into calves $(<1$ year), young $(>1-3$ years) and adult ( $>3$ years). Indigenous (Bos indicus) and crossbred (Holstein Friesian, Jersey, Bos taurus $\mathrm{X}$ Bos indicus) cattle were selected randomly. Ticks were preserved in $70 \%$ alcohol in clean, well-stoppered glass vials, labelled properly for their identification.

Different stages of unfed ticks were kept in lactophenol overnight for clearing. The morphological characters of the cleared tick specimens were studied under a stereoscopic binocular microscope/compound microscope for their identification following the taxonomic keys and description given by Sen and Fletcher (1962), Soulsby (1982) and Geevarghese and Mishra (2011). Data pertaining to tick species identification, their prevalence and infestation rate were categorized according to age, sex, type of cattle infested, body parts involved, districts of study area for further analysis. Per cent prevalence of ticks in animals was determined by the standard formula:

$\frac{\begin{array}{c}\text { No. of animals positive } \\ \text { to ticks }\end{array}}{\text { No. of animals inspected }} \times 100$

\section{Statistical analysis}

SAS Enterprise Guide 4.3 software program was employed for the data analysis using Chisquare $\left(\chi^{2}\right)$ test and Paired ' $t$ ' test. The results were expressed in percentage with $p$-value and the significance was determined with $\mathrm{p}$ value of $<0.05$. Odds Ratio was calculated according to the formula given by Schlesselman (1982).

\section{Results and Discussion}

\section{Prevalence of tick infestation according to tick species}

During the study period, out of 533 cattle examined, 266 were found infested with two species of ticks either in single or as mixed infestation. The overall prevalence of ticks recorded in the four districts of Assam was $49.90 \%$ and the tick species identified were Rhipicephalus (Boophilus) microplus (23.45 $\%$, Plate 1) and Haemaphysalis bispinosa (15.75\%, Plate 2) while mixed infestation of $R$. (B.) microplus and $H$. bispinosa was recorded as $10.69 \%$ (Table 1 and 2). On the contrary, higher prevalence rate of $R$. (B). microplus were recorded by many workers from India and abroad viz. 38-80\% by Lahkar (1991); 38.49\% by Patel et al.(2013); 42.89\% by Mandloi et al., (2016); $56.37 \%$ by Kakati (2013); 58.06\% by Singh and Rath (2013); $86.76 \%$ by Mohanta et al., (2011); $89.16 \%$ by Jaswal et al.(2014); $92.00 \%$ by Sen (2012) and $99.50 \%$ by Tsai et al., (2011). Prevalence 
of $15.94 \% H$. bispinosa, similar to our result was reported by Kabir et al., (2011) from Bangladesh and $11.61 \%$ by Lahkar (1991) from Assam. Contrary to our finding, lower prevalence of $7.79 \% \mathrm{H}$. bispinosa was recorded by Rajendran and Hafeez (2003) in cattle from Andhra Pradesh. However, Sen (2012) from Faridpur, Bangladesh recorded maximum prevalence rate of $56.0 \%$. As regards to mixed infestation, lower prevalence has been reported by several workers viz. $3.33 \%$ by Jaswal et al., (2014); $3.45 \%$ by Singh and Rath (2013) and $4.16 \%$ by Mandloi et al., (2016) which contradict our findings of $10.69 \%$.

The present result and earlier reports show that tick infestation is widely prevalent in different parts of India as well as abroad. The differences among the findings might be due to variation in the geographical region, climatic conditions prevailing in the experimental area, availability of cattle host, stage of the ticks examined, frequency of acaricide application, breed and resistance of the cattle, variation in method of study and collection of samples.

The characteristic morphological features of $R$. (B). microplus was short mouth parts, hexagonal basis capituli, presence of eyes, first coxa not bifurcated, anal groove inconspicuous, absence of festoon, presence of adanal shields, circular or oval spiracIes, 4/4 dentition, and presence of caudal process in case of male (Plate 1: B, C, E and F), whereas in the female scutum was partial, anal groove and caudal process was absent (Plate 1: D).

The morphological characteristics of $H$. bispinosa were absence of eyes, rectangular basis capituli, palps usually short and conical, second palpi having lateral projection beyond basis capitulum, first coxa not bifurcated, festoon present, absence of anal plate, anal groove posterior to anus and ovoid spiracle
(Plate 2: B,C and D), whereas spiracles were ovoid or comma shaped in females.

The district wise result showed highest infestation rate in cattle of Chirang $(54.67 \%)$ followed by Kokrajhar (49.21\%), Baksa $(48.63 \%)$ and Udalguri $(46.67 \%)$, the difference being statistically not significant $(\mathrm{P}>0.05)$. According to tick species, highest infestation of $R$. (B). microplus $(24.65 \%)$ was seen in Baksa whereas Udalguri recorded the lowest $(21.66 \%)$. Maximum positivity of $H$. bispinosa was recorded in Chirang (18.70\%) and lowest in Udalguri (13.33\%). Mixed infestation with both species was found highest in Udalguri (11.66\%) and lowest in Baksa $(9.58 \%)$, the difference was statistically non-significant.

\section{Breed wise prevalence of tick infestation}

The study on tick prevalence conducted on 533 cattle consisting of 456 indigenous and 77 crossbreds in four Indo-Bhutan border districts of Assam revealed higher positivity $53.50 \%$ (41/77) in cross bred cattle compared to $49.34 \%(225 / 456)$ in indigenous cattle (Table 3). It was observed that crossbred cattle were 1.17 times more susceptible to tick infestation than the indigenous animals. Similar findings were reported by Atif et al., (2012 a) and Sajeed et al., (2009). On the contrary, lower prevalence in crossbred (16.66\%) and higher in indigenous $(31.25 \%)$ cattle was recorded by Bilkis et al., (2011). Kakati (2013) also reported $49.75 \%$ tick infestation in crossbred and $88.61 \%$ in indigenous cattle from Assam. Wambura et al., (1998) noticed that Bos indicus (indigenous cattle) is relatively resistant to ticks as compared to crosses of Bos indicus and Bos taurus. They associated the higher concentration of serum complements for tick resistance in zebu cattle. Sajeed et al., (2009) opined that indigenous cattle breeds are more resistant to tick infestation than European breeds. 


\section{Age wise prevalence of tick infestation}

The study revealed highest prevalence in adult cattle $>3$ years of age $(56.61 \%)$ and lowest in calves $<1$ year of age $(41.74 \%)$ and in young cattle ( $>1-3$ years), the infestation rate was $52.89 \%$ (Table 4). Adult cattle were 1.82 times more susceptible to tick infestation than calves. Findings of Yakhchali and Hasanzadehzarza (2004) who recorded higher tick infestation in adult cows (60.8\%) than calves (20\%) in Oshnavich; Kabir (2008) with $84.0 \%$ in adults and lowest of $29.90 \%$ in calves and Sen (2012) with $97.07 \%$ as highest in adult cattle and lowest in calf $(53.33 \%)$ supports our present result. Contradictory to our findings, several workers from India and abroad reported low tick infestation on adults (Vatsya et al., 2007; Bilkis et al., 2011; Kabir, 2008; Patel et al., 2013; Mandloi et al., 2016). In a study conducted by Kabir et al., (2011) in cattle in Bangladesh, higher prevalence of ticks were observed in young $(46.28 \%)$ than in adult $(27.80 \%)$ where young cattle were 2.23 times more susceptible to infestation than adult. The prevalence of higher tick infestation in adults might be due to the fact that, while grazing adult cattle get more exposure to different stages of ticks (larvae, nymphs and adult) while calves are mostly kept in cattle sheds. The lower tick burden recorded in calves could be due to a combination of factors, including the frequent grooming of calves, especially head, ears and neck regions, by their dams and the smaller surface area of younger animals as compared to the adults. Furthermore, young animals seem to be more capable of protecting themselves from ticks by innate and cell mediated immunity, as per Mooring and Harte (2000). Manan et al., (2007) found that resistance in animal builds up as the age advances and the animals became more adoptable than in younger state irrespective of farm species.

\section{Sex wise prevalence of tick infestation}

During the present investigation, prevalence of tick was recorded higher in female $(53.57 \%)$ than in male $(44.80 \%)$ cattle (Table 5). Similar findings were reported by several workers (Kabir, 2008; Bilkis et al., 2011 and Sen, 2012) thus agreeing to our present report whereas Mandloi et al., ${ }^{[15]}$ found higher infestation in male $(66.10 \%)$ compared to female (58.06\%). Llyod (1983) found that the higher level of prolactin and progesterone hormone makes the female individual more susceptible to any infection. Etter et al., (1999) also found that immune-compromised animals acquired higher tick infestation. Moreover, reproduction stresses such as pregnancy, lactation makes the female more susceptible to such infestation as stated by Bilkis et al., (2011). Boophilus microplus was the more prevalent tick species recorded in females $(23.37 \%)$ followed by Haemaphysalis bispinosa $(15.90 \%)$ in the present study conforming to similar findings of $43.12 \% \mathrm{~B}$. microplus and $21.25 \%$ H. bispinosa in female cattle by Kabir et al., (2011). However, in male cattle, $H$. bispinosa was recorded more (18.66\%) compared to B. microplus (11.55 $\%)$. Though not statistically significant, male animals $(14.66 \%)$ were infested more than the females $(14.28 \%)$ by either species concomitantly (mixed infestation).

\section{Prevalence of tick infestation in cattle according to husbandry practices}

During the study, it was found that husbandry practices of cattle rearing had a marked influence on the prevalence of tick infestation in cattle as the prevalence was higher in free ranged indigenous cattle $(49.34 \%)$ than the stall fed crossbred animals (41.55\%) although not significant (Table 6). Kabir et al., (2011) also reported higher prevalence of tick in grazing cattle $(41.96 \%)$ than the stall-feeding (24.8\%) cattle. Similarly, Kakati (2013) 
observed higher tick infestation rate in open grazed indigenous cattle (88.61\%) compared to the stall fed crossbred (49.75\%) in Assam. Although the exact cause of higher prevalence of tick infestation in cattle cannot be explained but it can be hypothesized that regular washing of barn and animal, regular treatment of acaricide reduces the susceptibility of tick infestation in stall feeding animal whereas grazing cattle are moved from place to place for grazing, so susceptibility of tick infestation is higher (Kabir et al., 2011). Moreover, stall fed animals are less exposed to questing ticks (Rehman et al., 2017).

Table.1 Prevalence of tick infestation in cattle of Indo- Bhutan border districts of Assam

\begin{tabular}{|c|c|c|c|c|}
\hline District & $\begin{array}{c}\text { Number of } \\
\text { Cattle examined }\end{array}$ & $\begin{array}{c}\text { Number of } \\
\text { Cattle positive }\end{array}$ & Positive (\%) & $\begin{array}{c}\text { Significance } \\
\left.\text { value } \boldsymbol{\chi}^{\mathbf{2}}\right)\end{array}$ \\
\hline Kokrajhar & 128 & 63 & 49.21 & $\mathrm{P}=0.648$ \\
\hline Chirang & 139 & 76 & 54.67 & \\
\hline Udalguri & 120 & 56 & 46.67 & \\
\hline Baksa & 146 & 71 & 48.63 & \\
\hline Total & 533 & 266 & 49.90 & \\
\hline
\end{tabular}

Not significant, $\mathrm{P}>0.05$

Table.2 Tick species-wise prevalence in cattle of Indo-Bhutan border districts of Assam

\begin{tabular}{|c|c|c|c|c|c|}
\hline \multirow{3}{*}{$\begin{array}{l}\text { District } \\
(n=\text { No. of } \\
\text { animal } \\
\text { examined })\end{array}$} & \multicolumn{3}{|c|}{ Tick species recorded } & \multirow{3}{*}{$\begin{array}{c}\text { Overall } \\
\text { positive } \\
(\%)\end{array}$} & \multirow{3}{*}{$\begin{array}{c}\text { Significance } \\
\text { value } \\
\left(\chi^{2}\right)\end{array}$} \\
\hline & $\begin{array}{l}\text { Rhipicephalus } \\
\text { (B).microplus }\end{array}$ & $\begin{array}{c}\text { Haemaphysalis } \\
\text { bispinosa }\end{array}$ & Mixed & & \\
\hline & $\begin{array}{l}\text { No. positive } \\
(\%)\end{array}$ & $\begin{array}{c}\text { No. positive } \\
(\%)\end{array}$ & $\begin{array}{l}\text { No. positive } \\
(\%)\end{array}$ & & \\
\hline $\begin{array}{c}\text { Kokrajhar } \\
(\mathbf{n}=\mathbf{1 2 8})\end{array}$ & $\begin{array}{c}29 \\
(22.65)\end{array}$ & $\begin{array}{c}21 \\
(16.40)\end{array}$ & $\begin{array}{c}13 \\
(10.15)\end{array}$ & $\begin{array}{c}63 \\
(49.21)\end{array}$ & \multirow[t]{5}{*}{$\mathrm{P}<0.001$} \\
\hline $\begin{array}{l}\text { Chirang } \\
(\mathbf{n}=139)\end{array}$ & $\begin{array}{c}34 \\
(24.46)\end{array}$ & $\begin{array}{c}26 \\
(18.70)\end{array}$ & $\begin{array}{c}16 \\
(11.51)\end{array}$ & $\begin{array}{c}76 \\
(54.67)\end{array}$ & \\
\hline $\begin{array}{c}\text { Baksa } \\
(n=146)\end{array}$ & $\begin{array}{c}36 \\
(24.65)\end{array}$ & $\begin{array}{c}21 \\
(14.38)\end{array}$ & $\begin{array}{c}14 \\
(9.58)\end{array}$ & $\begin{array}{c}71 \\
(48.63)\end{array}$ & \\
\hline $\begin{array}{l}\text { Udalguri } \\
(\mathbf{n}=120)\end{array}$ & $\begin{array}{c}26 \\
(21.66)\end{array}$ & $\begin{array}{c}16 \\
(13.33)\end{array}$ & $\begin{array}{c}14 \\
(11.66)\end{array}$ & $\begin{array}{c}56 \\
(46.67)\end{array}$ & \\
\hline $\begin{array}{c}\text { Total } \\
(\mathbf{N}=\mathbf{5 3 3})\end{array}$ & $\begin{array}{c}125 \\
(23.45)\end{array}$ & $\begin{array}{c}84 \\
(15.75)\end{array}$ & $\begin{array}{c}57 \\
(10.69)\end{array}$ & $\begin{array}{c}266 \\
(49.90)\end{array}$ & \\
\hline
\end{tabular}

Highly significant, $\mathrm{P}<0$ 
Table.3 Prevalence of tick in crossbred and indigenous cattle of Indo-Bhutan border districts of Assam

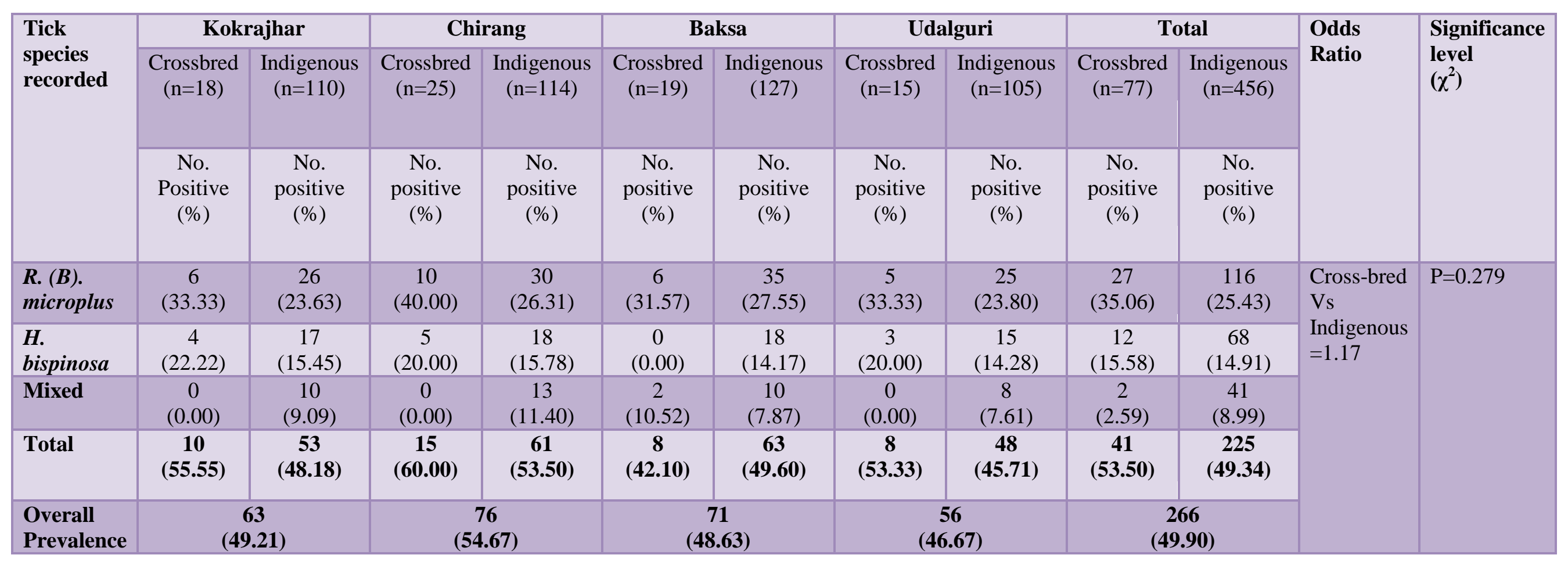


Table.4 Tick infestation in cattle according to their age and tick species involved

\begin{tabular}{|c|c|c|c|c|c|c|c|}
\hline \multirow[t]{2}{*}{ District } & \multirow{2}{*}{$\begin{array}{l}\text { Age group } \\
\text { (n=No. } \\
\text { examined) }\end{array}$} & \multicolumn{3}{|c|}{ Tick species recorded } & \multirow{2}{*}{$\begin{array}{l}\text { Total } \\
\text { No. } \\
\text { positive } \\
\text { (\%) }\end{array}$} & \multirow{2}{*}{$\begin{array}{l}\text { Odds } \\
\text { Ratio }\end{array}$} & \multirow{2}{*}{$\begin{array}{l}\text { Signific } \\
\text { ance } \\
\text { level } \\
\left(\chi^{2}\right)\end{array}$} \\
\hline & & $\begin{array}{l}R .(B) . \\
\text { microplus } \\
\text { No. } \\
\text { positive } \\
(\%)\end{array}$ & $\begin{array}{l}\text { H. bispinosa } \\
\text { No. } \\
\text { positive } \\
(\%)\end{array}$ & $\begin{array}{l}\text { Mixed } \\
\text { No. } \\
\text { positive } \\
(\%)\end{array}$ & & & \\
\hline \multirow[t]{3}{*}{ Kokrajhar } & $\begin{array}{l}\text { Calf } \\
(\mathrm{n}=50)\end{array}$ & $\begin{array}{l}12 \\
(24.00)\end{array}$ & $\begin{array}{l}8 \\
(16.00)\end{array}$ & $\begin{array}{l}3 \\
(6.00)\end{array}$ & $\begin{array}{l}23 \\
(46.00)\end{array}$ & \multirow{15}{*}{$\begin{array}{l}\text { Adult } \\
\text { Vs Calf } \\
=1.82\end{array}$} & \multirow{15}{*}{$\mathrm{P}=.009$} \\
\hline & $\begin{array}{l}\text { Young } \\
(\mathrm{n}=31)\end{array}$ & $\begin{array}{l}10 \\
(32.25)\end{array}$ & $\begin{array}{l}6 \\
(19.35)\end{array}$ & $\begin{array}{l}2 \\
(6.45)\end{array}$ & $\begin{array}{l}18 \\
(58.06)\end{array}$ & & \\
\hline & $\begin{array}{l}\text { Adult } \\
(\mathrm{n}=47)\end{array}$ & $\begin{array}{l}13 \\
(27.65)\end{array}$ & $\begin{array}{l}5 \\
(10.63)\end{array}$ & $\begin{array}{l}4 \\
(8.51)\end{array}$ & $\begin{array}{l}22 \\
(46.80)\end{array}$ & & \\
\hline \multirow[t]{3}{*}{ Chirang } & $\begin{array}{l}\text { Calf } \\
(\mathrm{n}=51)\end{array}$ & $\begin{array}{l}11 \\
(21.56)\end{array}$ & $\begin{array}{l}7 \\
(13.72)\end{array}$ & $\begin{array}{l}3 \\
(5.88)\end{array}$ & $\begin{array}{l}21 \\
(41.17)\end{array}$ & & \\
\hline & $\begin{array}{l}\text { Young } \\
(\mathrm{n}=35)\end{array}$ & $\begin{array}{l}10 \\
(28.57)\end{array}$ & $\begin{array}{l}6 \\
(17.14)\end{array}$ & $\begin{array}{l}4 \\
(11.42)\end{array}$ & $\begin{array}{l}20 \\
(57.14)\end{array}$ & & \\
\hline & $\begin{array}{l}\text { Adult } \\
(\mathrm{n}=53)\end{array}$ & $\begin{array}{l}14 \\
(26.41)\end{array}$ & $\begin{array}{l}11 \\
(20.75)\end{array}$ & $\begin{array}{l}10 \\
(18.86)\end{array}$ & $\begin{array}{l}35 \\
(66.03)\end{array}$ & & \\
\hline \multirow[t]{3}{*}{ Baksa } & Calf $(n=54)$ & $\begin{array}{l}15 \\
(27.77)\end{array}$ & $\begin{array}{l}6 \\
(11.11)\end{array}$ & $\begin{array}{l}3 \\
(5.55)\end{array}$ & $\begin{array}{l}24 \\
(44.44)\end{array}$ & & \\
\hline & $\begin{array}{l}\text { Young } \\
(\mathrm{n}=40)\end{array}$ & $\begin{array}{l}9 \\
(22.50)\end{array}$ & $\begin{array}{l}5 \\
(12.50)\end{array}$ & $\begin{array}{l}5 \\
(12.50)\end{array}$ & $\begin{array}{l}19 \\
(47.50)\end{array}$ & & \\
\hline & $\begin{array}{l}\text { Adult } \\
(\mathrm{n}=52)\end{array}$ & $\begin{array}{l}19 \\
(36.53)\end{array}$ & $\begin{array}{l}6 \\
(11.53)\end{array}$ & $\begin{array}{l}3 \\
(5.76)\end{array}$ & $\begin{array}{l}28 \\
(53.84)\end{array}$ & & \\
\hline \multirow[t]{3}{*}{ Udalguri } & Calf $(n=51)$ & $\begin{array}{l}10 \\
(19.60)\end{array}$ & $\begin{array}{l}6 \\
(11.76)\end{array}$ & $\begin{array}{l}2 \\
(3.92)\end{array}$ & $\begin{array}{l}18 \\
(35.29)\end{array}$ & & \\
\hline & $\begin{array}{l}\text { Young } \\
(\mathrm{n}=32)\end{array}$ & $\begin{array}{l}8 \\
(25.00)\end{array}$ & $\begin{array}{l}5 \\
(15.62)\end{array}$ & $\begin{array}{l}3 \\
(9.30)\end{array}$ & $\begin{array}{l}16 \\
(50.00)\end{array}$ & & \\
\hline & $\begin{array}{l}\text { Adult } \\
(\mathrm{n}=37)\end{array}$ & $\begin{array}{l}15 \\
(40.54)\end{array}$ & $\begin{array}{l}5 \\
(13.51)\end{array}$ & $\begin{array}{l}2 \\
(5.40)\end{array}$ & $\begin{array}{l}22 \\
(59.45)\end{array}$ & & \\
\hline \multirow[t]{3}{*}{ Total } & $\begin{array}{l}\text { Calf } \\
(\mathrm{n}=206)\end{array}$ & $\begin{array}{l}48 \\
(23.30)\end{array}$ & $\begin{array}{l}27 \\
(13.10)\end{array}$ & $\begin{array}{l}11 \\
(5.33)\end{array}$ & $\begin{array}{l}86 \\
(41.74)\end{array}$ & & \\
\hline & $\begin{array}{l}\text { Young } \\
(\mathrm{n}=138)\end{array}$ & $\begin{array}{l}37 \\
(26.81)\end{array}$ & $\begin{array}{l}22 \\
(15.94)\end{array}$ & $\begin{array}{l}14 \\
(10.14)\end{array}$ & $\begin{array}{l}73 \\
(52.89)\end{array}$ & & \\
\hline & $\begin{array}{l}\text { Adult } \\
(\mathrm{n}=189)\end{array}$ & $\begin{array}{l}61 \\
(32.27)\end{array}$ & $\begin{array}{l}27 \\
(14.28)\end{array}$ & $\begin{array}{l}19 \\
(10.05)\end{array}$ & $\begin{array}{l}107 \\
(56.61)\end{array}$ & & \\
\hline
\end{tabular}

Highly significant, $\mathrm{P}<0.01$. 
Table.5 Prevalence of tick species in relation to sex of cattle

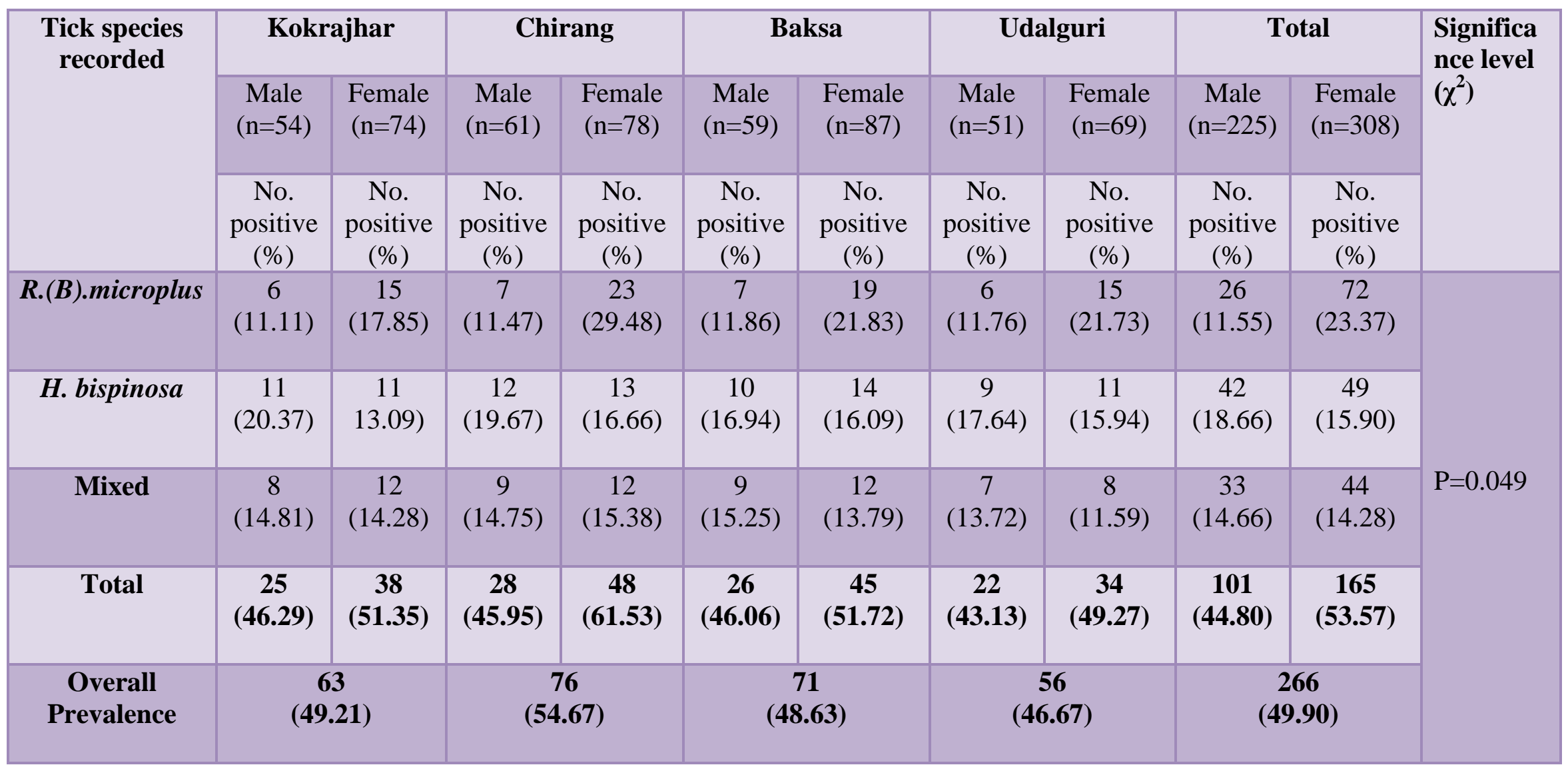


Table.6 Prevalence of tick infestation in cattle in relation to husbandry practices

\begin{tabular}{|c|c|c|c|c|}
\hline $\begin{array}{c}\text { Husbandry } \\
\text { practices } \\
(\mathbf{n}=\text { No. } \text { examined })\end{array}$ & Tick sp. recorded & $\begin{array}{c}\text { Number of } \\
\text { Cattle } \\
\text { positive }\end{array}$ & $\begin{array}{c}\text { Positive } \\
(\%)\end{array}$ & $\begin{array}{c}\text { Significance } \\
\text { level } \\
\left(\chi^{2}\right)\end{array}$ \\
\hline \multirow{4}{*}{$\begin{array}{c}\text { Stall fed } \\
\text { Crossbred } \\
(\mathbf{n}=77)\end{array}$} & R. (B).microplus & 12 & 15.58 & \multirow[t]{8}{*}{$\mathrm{P}=0.438$} \\
\hline & H. bispinosa & 7 & 9.09 & \\
\hline & Mixed infestation & 13 & 16.88 & \\
\hline & Total & 32 & 41.55 & \\
\hline \multirow{4}{*}{$\begin{array}{l}\text { Free ranged } \\
\text { Indigenous } \\
\quad(n=456)\end{array}$} & R.(B).microplus & 90 & 19.73 & \\
\hline & H. bispinosa & 60 & 13.15 & \\
\hline & Mixed infestation & 75 & 16.44 & \\
\hline & Total & 225 & 49.34 & \\
\hline
\end{tabular}

Not significant, $\mathrm{P}>0.0$

Table.7 Prevalence of ticks in cattle according to body parts involved

\begin{tabular}{|c|c|c|c|}
\hline Body parts & $\begin{array}{c}\text { No. of Animal } \\
\text { Positive }\end{array}$ & Positive \% & $\begin{array}{c}\text { Significance } \\
\text { level }\left(\boldsymbol{\chi}^{\mathbf{2}}\right)\end{array}$ \\
\hline Head & 170 & 63.90 & $\mathrm{P}=0.049$ \\
\hline Ear & 150 & 56.39 \\
\hline Neck & 190 & 71.42 & \\
\hline $\begin{array}{c}\text { Inguinal region, udder, } \\
\text { scrotum }\end{array}$ & 220 & 82.70 \\
\hline Back & 60 & 22.55 \\
\hline Tail switch & 80 & 30.07 \\
\hline Brisket & 175 & 65.78 \\
\hline
\end{tabular}

Significant, $\mathrm{P}<0.05$ 


\section{Plate.1 Morphological features of Boophilus microplus}

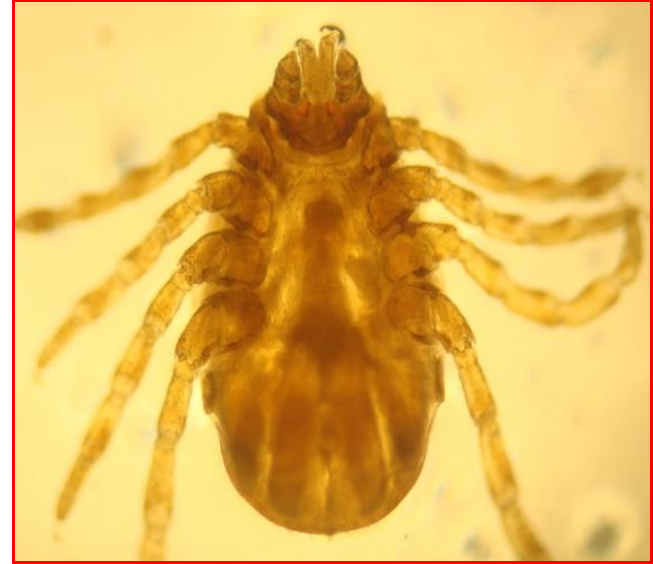

(A): Ventral view of adult male

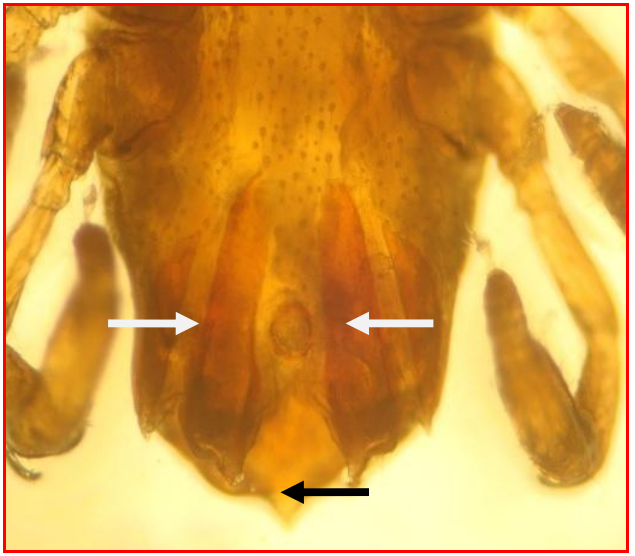

(C): Posterior portion (ventral view) showing Adanal shields (white arrow), Caudal process (black arrow)

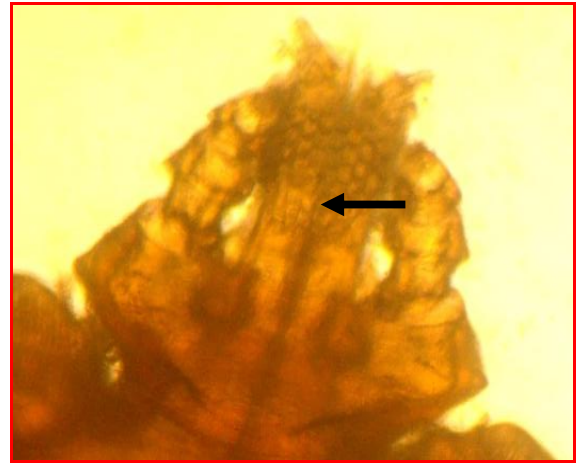

(E): Mouth part showing 4/4 Dentition in hypostome

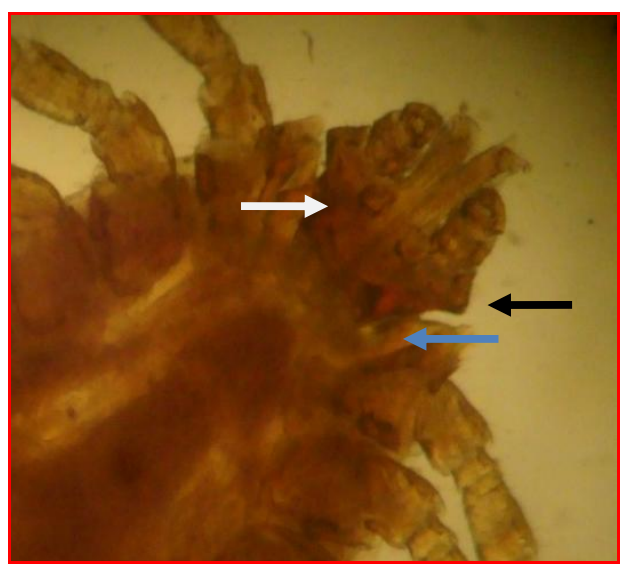

(B): Anterior portion showing hexagonal basis capitulum (white arrow) with lateral projection (black arrow) and Bifid Coxa-I (blue arrow)

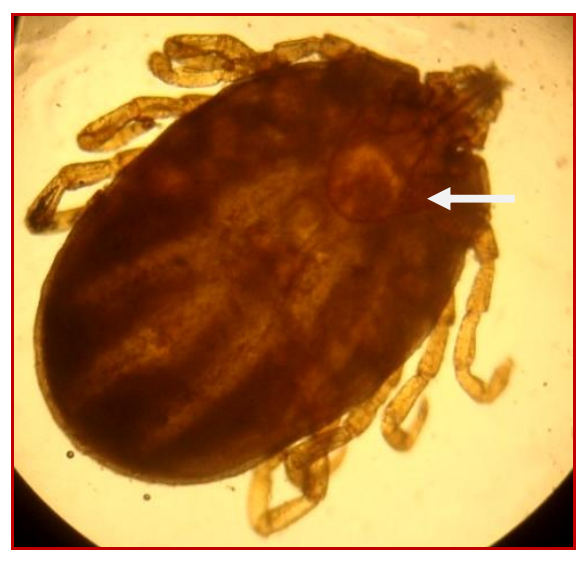

(D): Dorsal view of female adult showing partial scutum

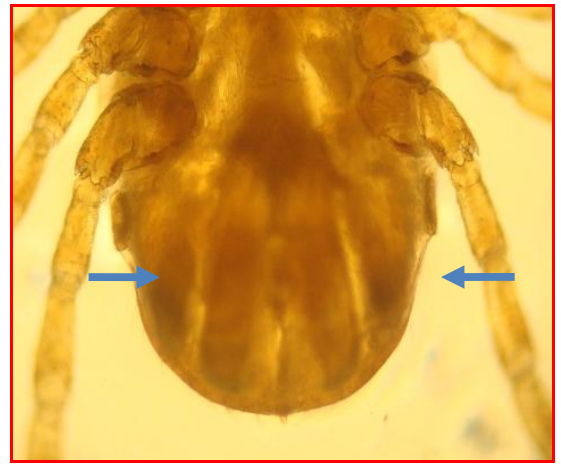

(F): Oval spiracle (blue arrow) of male tick 
Plate.2 Morphological features of Haemaphysalis bispinosa

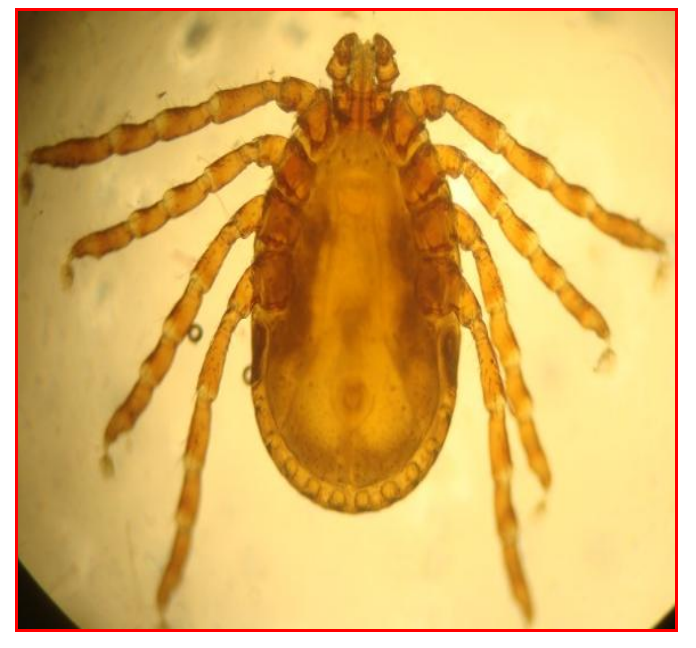

(A): Ventral view of male adult

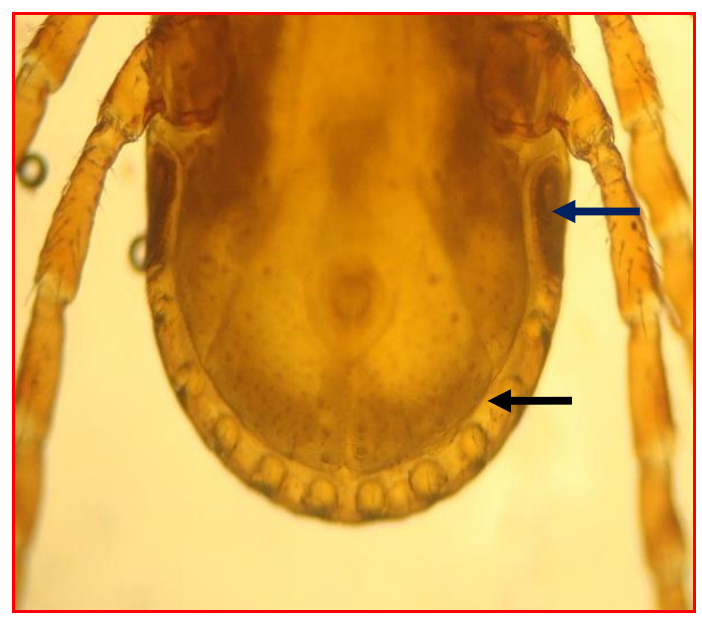

(C): Ventral view showing Festoons (black arrow) and Ovoid spiracle (blue arrow) of male tick

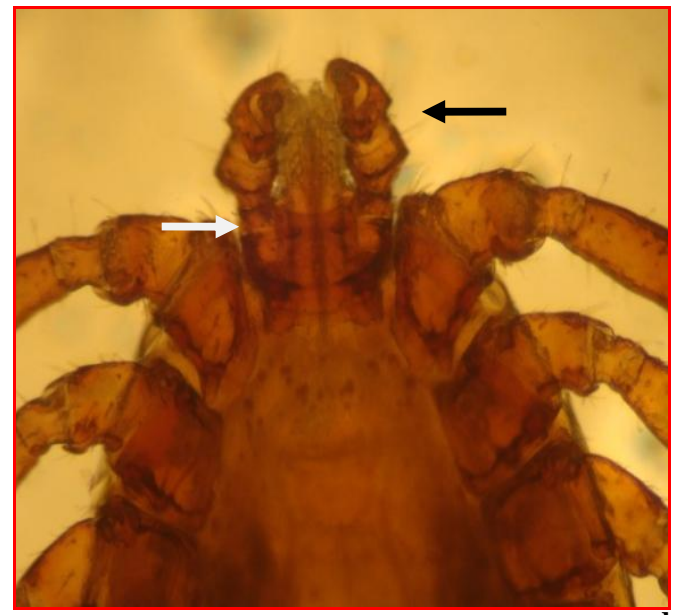

(B): Showing lateral projection of $2^{\text {nd }}$ palpi (black arrow), Rectangular Basis capitulum (white arrow)

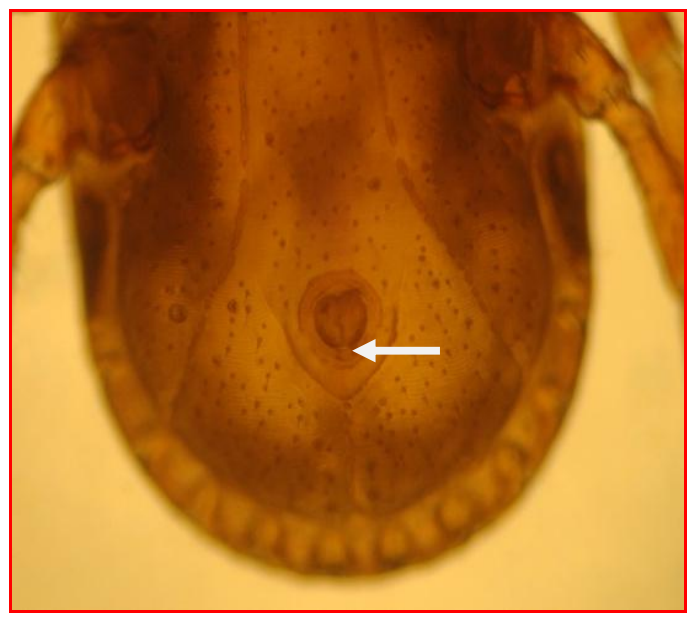

(D): Ventral view showing Anal groove (white arrow) 
Plate.3 Distribution of tick in different body parts of cattle (a)- Ear,(b)-Switch of tail, (c)-Axila, (d)-Neck, (e)-Inguinal region, (f)-Back
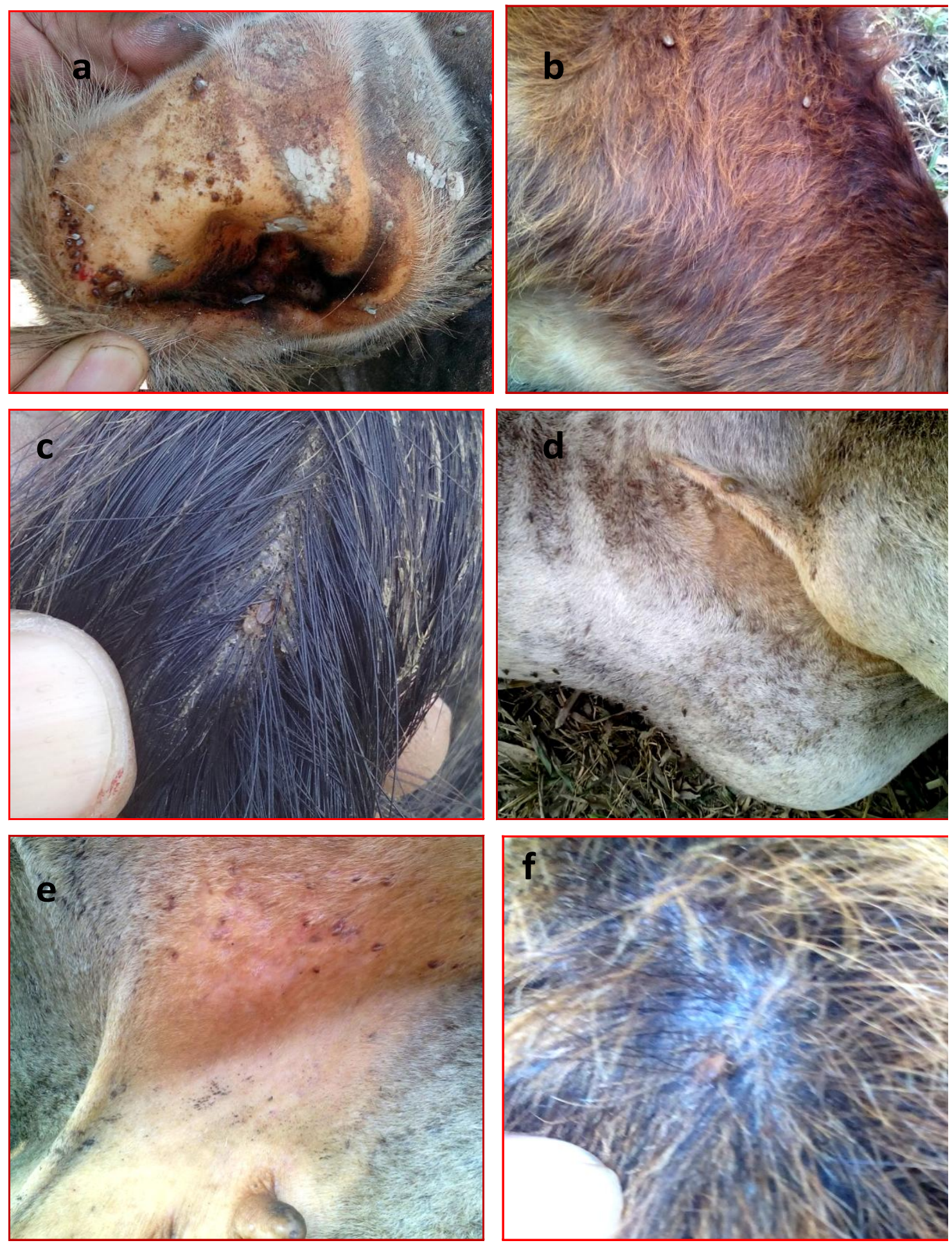
Prevalence of tick infestations in cattle according to body parts involved

During the study period, the ticks were found to attaching on whole body surface such as ear (pinna), head, neck, brisket, back, inguinal region, tail and tail switch. Inguinal region, udder in females and scrotum in the males was found to be infested in highest number of cattle $(82.70 \%)$ followed by neck $(71.42 \%)$, brisket region $(65.78 \%)$, head $(63.90 \%)$, ear (56.39\%), tail and tail switch (30.07\%) and back $(22.55 \%)$ as depicted in Table 7 and Plate 3. The distribution of tick is in conformation to findings of Atif et al., (2012 a) who observed that perineum, udder and external genitalia (98\%) were the most tick infested sites and Kabir et al., (2011). reported groin $(48.75 \%)$ as the most affected part of animal body while face and neck $(30 \%)$ was the least. However, findings of Patel et al., (2013) contradicts our present result who observed that the most common feeding sites for adult ticks were neck and axilla followed in order of preference by belly, groin, udder, perineal regions and tail. The differences in the attachment sites among the tick species suggest preferential feeding behaviour. The ticks most commonly infested the perineum and belly. The feeding site of ticks might have been influenced by attractant odours from the various predilection sites especially the perineum (Wanzala et al., 2004). The higher tick infestations on the perineum could also be ascribed to the fact that ticks prefer warm, moist and hidden sites with a good vascular supply and thin skin which helps in easy penetration of mouth parts into richly vascular area for feeding (Sajid et al., 2007; Muchenje et al., 2008). Moreover, birds such as cattle egret and other predators sit on the back of cattle and consume different stages of ticks, resulting in lesser tick population in the exposed back region. All these current study's findings are in agreement with those of Muchenje et al.,
(2008) who reported high tick infestations in secluded sites with less /short hair.

In conclusion, the present study conducted in Indo-Bhutan border districts of Assam showed abundance of ticks with $R$. (Boophilus) microplus as the probable common tick vector.

\section{Acknowledgements}

The authors are thankful to the Dean, College of Veterinary Science and DBT funded project ADMaC, A.A.U., Khanapara for providing the laboratory facilities and administrative support.

\section{References}

Atif, F.A., Khan, M.S., Iqbal, H.J., Ali, Z. and Ullah, S. 2012a. Prevalence of cattle tick infestation in three districts of the Punjab, Pakistan. Pakistan journal of science. 64 (1): 49-54.

Bilkis, M.F., Mondal, M.M.H., Rony, S.A., Islam, M.A. and Begum, N. 2011. Host determinant based prevalence of ticks and lice in Cattle (Bos indicus) at Bogra district of Bangladesh. Progressive Agriculture. 22: 65 - 73 .

Biswas, S. 2003. Role of veterinarians in the care and management during harvest of skin in livestock species. In: Proceedings of National seminar on Leather Industry in Today's Perspective, Kolkata, India.62-64.

Etter, E., Chartier, C., Lefrileux, Y. and Borgid, L.P. 1999. The influence of nutrition on the periparturient rise in fecal egg counts in dairy goats. Revue de Medicine Veterinaire. 150: 975-980.

Geevarghese, G. and Mishra, A.C. 2011. Haemaphysalis ticks of India. $1^{\text {st }}$ Edition, Elsevier London. Pp. 255.

Jaswal, H., Bal, M.S., Singla, L.D., Sharma, 
A., Kaur, P., Mukhopadhyay, C.S. and Juyal, P.D. 2014. Application of msp1 $\beta$ PCR and 16S rRNA semi nested PCRRFLP for detection of persistent anaplasmosis in tick infested cattle. International Journal of Advance Research. 2 (8): 188-196.

Jonsson, N.N., Mayer, D.G., Matschoss, A.L., Green, P.E. and Ansell, J. 1998. Production effects of cattle tick (Boophilus microplus) infestation of high yielding dairy cows. Veterinary Parasitology. 78: 65-77.

Kabir, M.H.B. 2008. Epidemiological surveillance of tick in Dinajpur district. M. S. Thesis. Department of Parasitology, Bangladesh Agricultural University, Mymensingh.

Kabir, M.H.B., Mondal, M.M.H., Eliyas, M., Mannan, M.A., Hashem, M.A., Debnath, N.C., Miazi, O.F., Mohiuddin, C., Kashem, M.A., Islam, M.R. and Elahi, M.F. 2011. An epidemiological survey on investigation of tick infestation in cattle at Chittagong District, Bangladesh. African Journal of Microbiology Research. 5(4): 346-352.

Kakati, P. Studies on ticks and tick borne haemoparasitic infection of cattle in Assam. M.V.Sc. Thesis submitted to Assam Agricultural University, Jorhat, Khanapara 2003; Pp: 107.

Lahkar, B.C. Studies on Ixodid ticks with special reference to Boophilus microplus (Canestrini, 1987). Ph.D. Thesis, Assam Agricultural University, Jorhat. 1991.

Lloyd, S. Effect of pregnancy and lactation up on infection. Veterinary Immunology and Immunopathology. 1983; 4: 153176.

Mandloi, U.K., Jayraw, A.K., Haque, M. and Jamra, N. 2016. Prevalence of Ixodid Ticks in cattle population of Indore, Madhya Pradesh. The Indian Journal of Veterinary Sciences and Biotechnology.
12(2): 62-65.

Mohanta, U.K. and Anisuzzaman, Mondal M.M.H. 2011. Tick and tick borne protozoan diseases of livestock in the selected hilly areas of Bangladesh, International Journal of Agricultural Research, Innovation and Technology. 1 (1\&2): 60-63.

Manan, A., Khan, Z., Ahmad and B, 2007. Abdullah. Prevalence and identification of ixodid tick genera in frontier region Peshawar. Journal of Agricultural and Biological Sciences. 2(1): 21-25.

Mooring, B. and Harte, H. Testing the interspecific body size principle in ungulates: the smaller they come, the harder they groom. Animal Behaviour. 2000; 60: 35-45.

Muchenje, V., Dzama, K., Chimonyo, M. and Raats, J.G, Strydom PE. Tick susceptibility and its effects on growth performance and carcass characteristics of Nguni, Bonsmara and Angus steers raised on natural pasture. Animal. 2008; 2: 298-304.

OIE Terrestrial Manual, Bovine Trypanosomosis (2013), Theileriosis and Babesiosis (2014), Anaplasmosis (2015), World Organization for Animal Health, Paris, France,2013-15; www.oie.int

Patel, G., Shanker, D., Jaiswa, 1.A.K., Sudan, V. and Verma, S.K. Prevalence and seasonal variation in ixodid ticks on cattle of Mathura district, Uttar Pradesh. Journal of Parasitic Diseases. 2013; 37(2): 173-176.

Phanchung et al., Small holder dairy farming in Bhutan: Characteristics, constraints and development opportunities 2012; Chapter 2, pp. 18-25.

Rai, M. The fauna of Northeast India, 2008.

Rajendran, C. and Hafez, M. 2003. Prevalence of Ixodid ticks on crossbred cattle in and around Tirupati. Journal of Veterinary Parasitology. 17: 147-149. 
Rehman, A., Nijhof, A.M., Sauter-Louis, C., Schauer, B., Staubach, C. and Conraths, F.J. 2017. Distribution of ticks infesting ruminants and risk factors associated with high tick prevalence in livestock farms in the semiarid and arid agroecological zones of Pakistan. Parasites \& Vectors. 10:190.

Sajid, M.S., Iqbal, Z., Khan, M.N., Mohammad, G. and Iqbal, M.U. 2007. Effect of Hyalomma ticks (Acari: Ixodidae) on milk production of dairy buffaloes (Bos bubalus bubalis) of Punjab (Pakistan). Italian Journal of Animal Science. 6: 939-941.

Sajeed, M.S., Iqbala, Z., Khan, M.N., Ghulam, M. and Khan, K.M. 2009. Prevalence and associated risk factors for bovine tick infestation in two districts of lower Punjab, Pakistan. Preventive Veterinary Medicine. 92(4):386-391.

Sen, P.C. 2012. A cross sectional study on the prevalence and distribution of tick on cattle at Sadar and Madhukhali Upazila of Faridpur, Bangladesh, M. S. Thesis, Department of Parasitology, Bangladesh Agricultural University, Mymensingh.

Sen, S.K. Fletcher, TB. 1962. Veterinary entomology and acarology for India.

Singh, N.K. and Rath, S.S. 2013. Epidemiology of Ixodid ticks in cattle population of various agro-climatic zones of Punjab, India. Asian Pacific Journal of Tropical Medicine. Pp. 947951.

Soulsby, E.J.L. 2012. Helminths, arthropods and protozoa of domesticated animals. $7^{\text {th }}$ ed. London: Bailliere Tindall. pp: 809.

Tshering, G. and Dorji, N. 2013. Prevalence of gastrointestinal parasites in free range cattle: A case study in Haa district, Bhutan. Journal of Animal Health and Production. 1: 36-37.

Tsai, Y.L., Wenchen, J.P., Chen, S.K., Hsieh, J.C. and Chuang, S.T. 2011.Survey of Species of ticks infesting cattle in Taiwan. Taiwan Veterinary Journal. 37: 74-82.

Vatsya, S., Yadav, C.L., Kumar, R.R. and Garg, R. 2007. Seasonal activity of Boophilus microplus on large ruminants at an orgnised livestock farm. Journal of Veterinary Parasitology. 21 (2): 125128.

Wambura, P.N., Gwakisa, P.S., Silayo, R.S. and Rugaimukamu, E.A. 1998. Breedassociated resistance to tick infestation in Bos indicus and their crosses with Bos Taurus. Vet. Parasitol. 77: 63-70.

Wanzala, W., Sika, N.F.K., Gule, S. and Hassanali, A. 2004. Attractive and repellent host odours guide ticks to their respective feeding sites. Chemoecology. 14:229-232.

Yakhchali, M. and Hasanzadehzarza, H.S. 2004. Study on some ecological aspects and prevalence of different species of hard ticks (Acarina: Ixodidae) on cattle, buffalo and sheep in Oshnavieh suburb. Pajouhesh-va-Sazandegi. Animal and Fishery Sciences. 63: 30-35.

\section{How to cite this article:}

Dipanjali Mushahary, Kanta Bhattacharjee, Prabhat Chandra Sarmah, Dilip Kr. Deka, Tirtha Nath Upadhyaya and Munmi Saikia. 2019. Prevalence of Ixodid Ticks on Local and Crossbred Cattle in Indo-Bhutan Border Districts of Assam, India. Int.J.Curr.Microbiol.App.Sci. 8(05): 2168-2183. doi: https://doi.org/10.20546/ijcmas.2019.805.256 